Article

\title{
The Impact of Single-Family Rental REITs on Regional Housing Markets: A Case Study of Nashville, TN
}

\author{
Ken Chilton ${ }^{1}$, Robert Mark Silverman ${ }^{2, *} \mathbb{C}$, Rabia Chaudhry ${ }^{1}$ and Chihaungji Wang ${ }^{2}$ \\ 1 Department of Public Administration; Tennessee State University, Nashville, TN 37209, USA; \\ kchilton@Tnstate.edu (K.C.); rabia.m.chaudhry@gmail.com (R.C.) \\ 2 Department of Urban and Regional Planning; University at Buffalo; Buffalo, NY 14214, USA; \\ chihuang@buffalo.edu \\ * Correspondence: rms35@buffalo.edu; Tel.: +1-716-829-5882
}

Received: 16 July 2018; Accepted: 18 September 2018; Published: 20 September 2018

check for updates

\begin{abstract}
The U.S. Congress authorized the creation of real estate investment trusts (REITs) in 1960 so companies could develop publically traded real estate investment portfolios. REITs focus on commercial property, retail property, and rental property. During the last decade, REITs became more active in regional housing markets across the U.S. Single-family rental (SFR) REITs have grown tremendously, buying up residential properties across the country. In some regional housing markets, SFR REITs own noticeable shares of single-family homes. In those settings, SFR REITs take large numbers of housing units off of real estate markets where homeownership transactions occur and manage these properties as part of commercial rental inventories. This has resulted in a new category of multiple property owners, composed of institutional investors as opposed to individual investors, which further exacerbates property wealth concentration and polarization. This study examines the socio-spatial distribution of properties in SFR REIT portfolios to determine if SFR REIT properties tend to cluster in distinct areas. This study will focus on the regional housing market in Nashville, TN. Nashville has one of the most active SFR REIT sectors in the country. County tax assessor records were used to identify SFR REIT properties. These data were joined with U.S. Census data to create a profile of communities. The data were analyzed using SPSS statistical software and GIS software. Our analysis suggests that neighborhoods with clusters of SFR REITs fit the SFR REIT business model. Clusters occur in communities with newer homes, residents with higher levels of educational attainment, and middle to upper-middle incomes. The paper concludes with several recommendations for future research on SFR REITs.
\end{abstract}

Keywords: real estate investment trusts (REITs); single-family rental real estate investment trusts (SFR REITs); institutional housing investors; real estate speculation

\section{Introduction}

\subsection{The Emergence of Real Estate Investment Trusts}

Congress authorized the creation of real estate investment trusts (REITs) in 1960 so companies could develop publically traded real estate investment portfolios [1]. REITs have historically focused on commercial property, retail property, and rental property. During the last decade, REITs became more active in regional housing markets across the country [2-5]. Growth in single-family rental (SFR) REITS was initiated during the 2007-2009 housing crisis [2] when institutional investors began acquiring foreclosed properties and converting them from owner-occupied units to rentals. The conversion of owner-occupied housing into rental property held in portfolios of institutional investors grew out 
of the global financial crisis and is part of a broader trend toward what has been referred to as the financialization of real estate and housing markets [6-11].

Financialization encompasses a shift from a mortgage finance system that is localized in nature and relatively protected from market speculation by the public sector to one that is integrated into the global system of finance and investment. This shift had several implications for real estate and housing markets. First, income stagnation and growth in the risk of borrower default associated with mortgage lending has diminished the role of homeownership as a mechanism for household wealth accumulation. Heightened risk of default and foreclosure has facilitated the expansion of secondary mortgage markets where loans are purchased and pooled to shield investors. Second, housing has increasingly been used to leverage investment and bolster global financial markets. This has been enabled by the creation of securitized real estate products on the secondary market allowing private equity investors, pension funds, hedge funds, banks, and other large institutional investors to purchase shares of real estate portfolios on global markets. Securitization has shifted the emphasis on real estate investment from a focus on the appreciation of individual property values to an emphasis on overall portfolio performance and investment yields. In essence, securitization has created a more liquid real estate investment product that can be scaled up, providing institutional investors at the national and global level with more predictable and stable investments. Finally, the shift to an emphasis on investing in real estate securities as opposed to individual properties has created a new class of institutional owners, SFR REITs, who compete directly with individuals engaged in traditional homeownership and locally based "mom and pop" landlords. These institutional owners are better capitalized and able to build real estate portfolios that attract global investment to housing markets that were previously more responsive to local economic conditions. The entrance of SFR REITs backed by securitized assets inflates housing prices in local markets and depress traditional mortgage activity.

In the wake of the global financial crisis, conditions have been ripe for the financialization of real estate and the expansion of SFR REITs. Large-scale property market devaluation created large inventories of distressed assets that investors could purchase at discounted prices. Securitizing and pooling these properties into single portfolios allowed institutional investors to reduce their financial risk and generate more predictable yields from their investments. Moreover, there was a growing market for rental properties in this segment of the housing market, since indebtedness and the lack of creditworthiness among former homeowners and young families had become more acute.

The SFR REIT sector has grown tremendously since that time, both internationally and in the U.S. Although the latter, particularly the Nashville metropolitan area, is the focus of the analysis in this article, research on SFR REITs has emerged in Ireland, Spain, Greece, and across Europe in response to the same structural shifts brought about by the global financial crisis [12,13]. In the U.S. context, from the onset of the global financial crisis to 2007 over $\$ 33$ billion had been invested in over 200,000 properties owned by REITs [4]. Although SFR REITs account for less than $1 \%$ of all single-family housing units across the U.S., their presence in some markets is more pronounced. SFR REIT holdings cluster in suburban Sunbelt locations, metropolitan areas in the south and southwestern U.S. that began a prolonged period of expansion following the Second World War. These locations were heavily impacted by the 2007-2009 housing crisis and where the housing stock is relatively new [3]. According to Attom Data Solutions, 8,027,048 homes were foreclosed on from 2008-2010. In 2010, RealtyTrac reported 124,720 foreclosure filings in metropolitan Phoenix, AZ, 61,674 in metropolitan Tampa, and 38,355 bank repossessions in metropolitan Atlanta [14].

Some of the metropolitan areas with the largest concentrations of SFR REITs are Phoenix, Atlanta, Tampa, and Dallas. Within these regional housing markets, SFR REIT holdings cluster geographically. This clustering allows for institutional investors to take advantage of technology, similarities in construction materials, and build economies of scale based on standardized management practices [5].

The concentration of SFR REIT properties and the movement of them into commercial rental inventories removes large numbers of housing units from real estate markets where homeownership transactions occur. In addition to their impact on inventories of units available for homeownership, 
SFR REIT properties tend to be marketed to middle and upper-middle class households and are inaccessible to households seeking affordable rentals. For example, 1.14\% of SFR REIT properties are rented to tenants receiving rent subsidies under the federal housing choice voucher $(\mathrm{HCV})$ program, [3]. Where SFR REITs cluster, there is concern about tightening markets for homeowner occupied units, rising rents, and an absence of units available to households seeking affordable housing. A recent report concluded, "When houses are sold to cash-carrying investors for conversion into rentals, prospective homeowners and "mom and pop" landlords are crowded out of the market, and communities suffer-particularly communities of color [15]. This conclusion is contextual and requires further discussion.

A critical variable in determining the outcome of foreclosure properties is the health of the regional housing market. In cities that have not recovered from the most recent recession or in cities with long histories of concentrated poverty and derelict properties, foreclosures tend to aggravate existing community reinvestment. A 2010 publication by the Boston and Cleveland Federal Reserve Banks includes case studies of neighborhoods in rust belt cities, mill towns, and suburbs that had large portfolios of real estate-owned (REO) properties [16]. These communities were seeking new uses for REO properties in areas lacking market demand after the housing market crashed.

Reid [17] found a tremendous increase in suburban foreclosures in many fast-growing suburbs primarily in California, Nevada, and Arizona. Many of these properties were being purchased by investors, both individuals and institutions. Immergluck [18] analyzed REO-purchases in Atlanta prior the emergence of SFR REITs and found high percentages of investors buying up low-income housing in the city. This trend is not unique to the U.S. For example, Donner [19] found institutional investors rather than individual homeowners tend to buy foreclosed properties in Stockholm, Sweden. Because of their ability to gain access to investment capital, institutional investors had a greater ability to take advantage of property discounts.

In general, homeownership rates in the U.S. have declined since the great recession. The shift to what some scholars refer to as a "rentership society" [15] or the "generation rent" [20,21] phenomenon is found in a transnational context as a result of the global financial crisis. Consequently, single-family rentals are the fastest growing segment of the housing market; and the bulk of landlords remain small property entrepreneurs [22]. But, some analysts expect large institutional investors to grow in market presence because they have learned how to leverage rental properties. Gary Beasley, the former co-CEO of Starwood Waypoint Residential Trust now part of Colony Starwood Homes, one of the largest SFR REITs in the US, attributed the emergence of institutional investors in the residential market, in part, to, "cloud and mobile computing, [which] fundamentally changed the way distributed assets could be managed, allowing large buyers of single-family rentals to build killer platforms in the cloud that allowed us to run margins that rivaled apartments" [23]. The adaptation of new technologies and access to large blocks of capital have allowed institutional investors to scale up and emerge as a new category of multiple property owners distinct from individual investors who have traditionally occupied this niche in the housing market. The growing influence of institutional investors in the single-family rental market has exacerbated property wealth concentration and polarization.

\subsection{A Shifting Business Model}

As the SFR REIT sector has developed, there have been two noticeable shifts in the business model that institutional investors follow. First, the sale of rent-backed securities has become the primary tool used by SFR REITs to raise capital for home purchases $[15,24]$. This practice began in 2013 when one of the larger SFR REITs at the time, Blackstone, backed a $\$ 479$ million loan with anticipated rents from 3000 single-family rental properties [24]. The loan was then securitized and sold to investors who receive monthly dividends from rental income generated by the properties. The ability to securitize their portfolios allows SFR REITs to raise capital that can be used for cash purchases of new properties. By 2016, SFR REITs and other large institutional investors had moved to an almost $100 \%$ cash buying rate for new properties, compared to smaller, individual investors who 
continued to purchase new properties with cash less than $50 \%$ of the time [25]. Greater access to cash purchasing for SFR REITs reduced their reliance on mortgage financing and other forms of borrowing to acquire properties. This, in turn, lowered their costs, allowed them to make more competitive offers for properties, and accumulate a larger proportion of available units in targeted real estate markets. This business model gave SFR REITs the ability to expand their portfolios and gain greater control of the local rental markets where they operated. However, securitization also increased the pressure on SFR REITs to deliver returns to investors, which resulted in upward pressure on rents [26]. Ironically, the business model adopted by SDR REITs is strikingly similar to the business model used by financial institutions before the 2007-2009 financial crisis built on mortgage-backed securities. Thus, SFR REITs' portfolios are exposed to any volatility in local housing markets where their investments are concentrated.

In addition to a shift toward the use of rent-backed securities to raise capital for cash purchases of properties, SFR REITs also shifted toward increased standardization and automation of their property management systems. Unlike traditional mom and pop landlords who are locally-based and own a small number of properties, SFR REITs include properties from across the country in their portfolios. Table 1 summarizes the portfolios of some of the largest SFR REITs. Many of the largest REITs are absentee landlords, headquartered in places far from their tenants. For example, American Homes 4 Rent is headquartered in Agora Hills, CA; the Blackstone Group, is headquartered in Brooklyn, NY, and Colony Starwood Homes is headquartered in Phoenix, AZ. The ability to manage large portfolios of properties remotely is made possible by internet-based leasing and management systems driven by real-time data analytics $[5,20,25]$. Coupled with these technology platforms are standardized leases, and property management practices focused on maximizing profits. The business model adopted by SFR REITs has been critiqued for lease terms, fee structures, annual rent increases, and eviction practices that work to the disadvantage of tenants $[15,25]$.

Table 1. Summary of Major SFR REITs Portfolios.

\begin{tabular}{cccc}
\hline Company & Number of Homes & Investor & Investment \\
\hline Invitation Homes & 48,038 & Blackstone & $\$ 8.9$ billion \\
American Homes 4 Rent & 48,000 & Alaska Permanent Fund & $\$ 9.6$ billion \\
Colony Starwood & 30,844 & Colony Capital; Starwood Capital & $\$ 5.9$ billion \\
Progress Residential & 17,333 & Goldman Sachs & $\$ 3.0$ billion \\
Tricon & 17,249 & Tricon Capital & $\$ 1.4$ billion \\
\hline \multicolumn{2}{c}{${ }^{*}$ Colony Starwood merged with Invitation Source: Adapted from Abood, 2018. }
\end{tabular}

\subsection{The Need for More Local Research}

Although there has been some analysis of national trends related SFR REITs by industry groups, policy think tanks, and journalists, there remains a need for scholars to conduct empirical research on this sub-sector of the housing market. In particular, there is a need for scholarly analysis of the degree to which SFR REIT properties cluster in local markets. This study moves in that direction by conducting an exploratory analysis of SFR REIT clusters to generate questions for future inquiry. It focuses on the regional housing market in Nashville, TN. This market has one of the most active SFR REIT sectors in the country. This study examines the socio-spatial distribution of properties in SFR REIT portfolios to determine the degree to which SFR REIT properties cluster in distinct areas. In particular, we examine the degree to which attributes of middle-class areas, such as higher levels of educational attainment, larger household size, and higher household income are correlated with SFR REIT clustering. We also scrutinize disparities in SFR REIT clustering based on neighborhood racial and ethnic composition. Moreover, we examine the degree to which characteristics of the housing stock, such as the age of the housing stock and housing costs correlate with SFR REIT clustering. A better understanding of how these community characteristics relate to SFR REIT clustering will inform and assist in refining future research questions. 


\section{Methods}

This study focuses on the regional housing market in Nashville, TN. Data were collected from the following six counties: Davidson, Maury, Rutherford, Sumner, Williamson, and Wilson. Tax assessor records for 2017 were used to identify addresses and purchase prices for 2258 SFR REIT properties in greater Nashville. These data were aggregated at the census tract level and joined with 2015 five-year estimates from the American Community Survey (ACS) to create a profile of communities. In total, 325 census tracts were included in the analysis. Data were aggregated at the tract level to identify clusters of SFR REIT properties and compare population and housing characteristics across those clusters. The data were analyzed using SPSS statistical software and geocodes for analysis with GIS software. This analysis was descriptive and exploratory in nature. It was used to gain insights into distinct demographic patterns where SFR REITs cluster which can inform future research.

\section{Nashoille Overview}

The Nashville, TN region is one of the fastest growing regions in the country. The housing industry has rebounded from the crash, and the number of new building permits applied for by developers in $2017(19,292)$ surpassed the previous high in 2005 (16,654). Home prices have appreciated considerably over the last five years. In 2017, the average sales price of housing rose by $8 \%$ to $\$ 275,000$ [27], this continued a growth trend that began in the previous two years. Data from the U.S. Federal Housing Finance Agency shows that the housing price index for the Nashville region has steadily increased over time without a major drop during the recession. In contrast, the Tampa housing price index peaked in the fourth quarter of 2006 and experienced a 44\% decline between 2006 and 2012. Unlike Tampa, housing prices in Nashville were relatively low before the recession. The swing in market conditions was not as volatile in Nashville as in Tampa.

The major SFR REITs active in Nashville are American Homes 4 Rent, Invitation Homes, Colony Starwood, and Progress Residential. Table 2 shows the total number of homes owned by county in the Nashville region in 2015. At that time, SFR REITs owned approximately 2970 homes in the Nashville region- $0.68 \%$ of the single-family detached housing stock. The companies owned larger shares of the single-family detached housing stock in Rutherford (0.91\%), Williamson (0.83\%), and Wilson $(1.17 \%)$ counties. Each of these counties is middle-income, working-class suburbs outside of Nashville proper (Davidson County).

Table 2. SFR REIT Activity in Metropolitan Nashville by County (2015 ACS 5yr Estimates).

\begin{tabular}{cccc}
\hline County & SFR REIT Properties & Total Single Family Detached Units & Percent REIT-Owned \\
\hline Davidson & 825 & 176,579 & $0.47 \%$ \\
Rutherford & 733 & 80,387 & $0.91 \%$ \\
Williamson & 512 & 61,511 & $0.83 \%$ \\
Wilson & 454 & 38,818 & $1.17 \%$ \\
Sumner & 285 & 53,174 & $0.54 \%$ \\
Maury & 161 & 26,921 & $0.60 \%$ \\
TOTAL & 2970 & 437,390 & $0.68 \%$ \\
\hline
\end{tabular}

\section{Results and Interpretation}

Table 3 summarizes the census data for metropolitan Nashville. In addition to overall characteristics for the metropolitan area, census tracts are aggregates for: tracts with no SFR REITs; tracts where there was at least one SFR REIT, and in tracts where at least $1 \%$ of single-family units were SFR REITs which is roughly the national average for the share of single-family housing units that are SFR REITs [5]. Thus, the latter group of tracts represented tracts with clusters of SFR REIT properties. 
Table 3. Metropolitan Nashville Population and Housing Characteristics (2015 ACS 5yr Estimates).

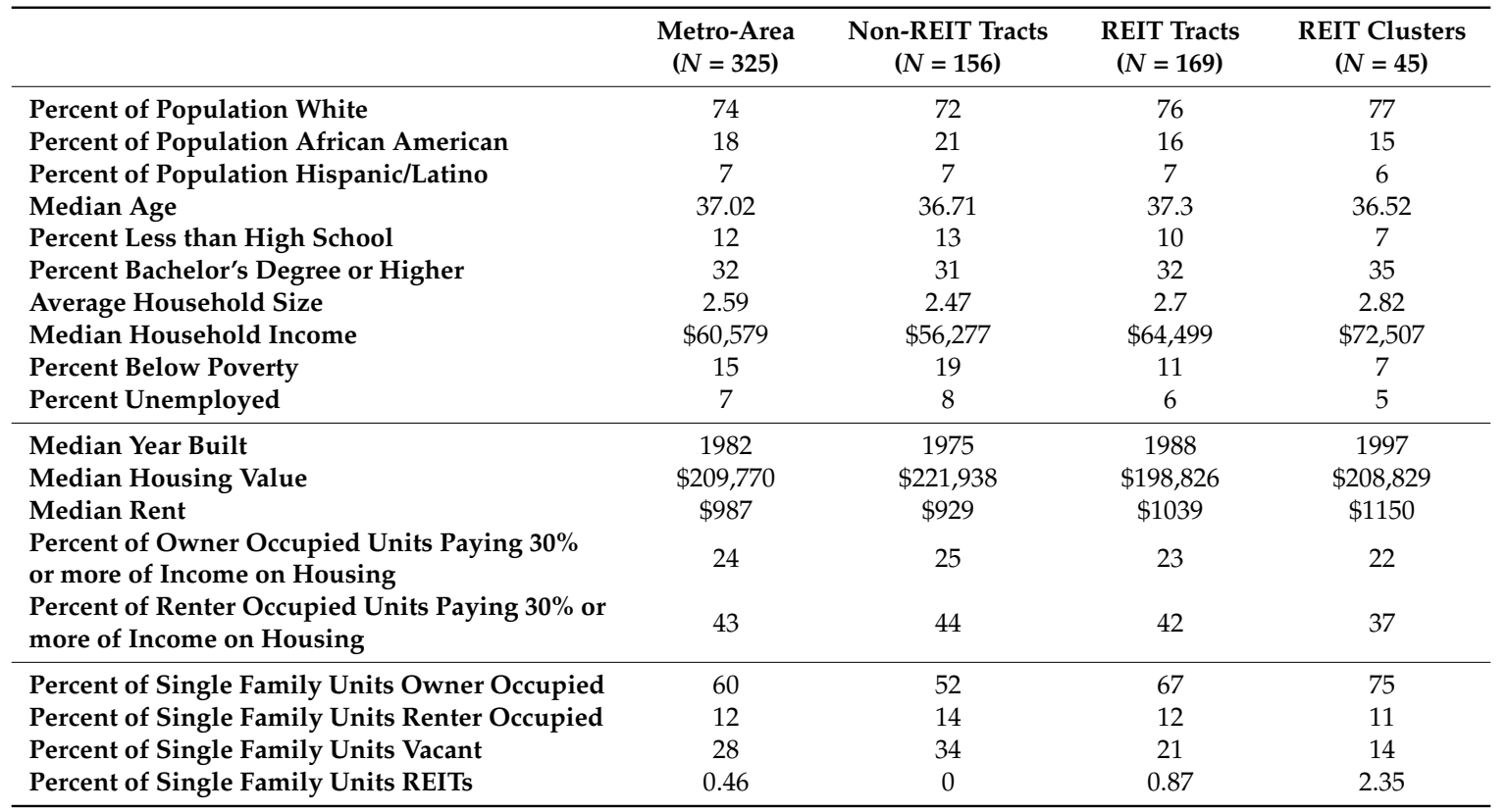

Table 3 suggests that SFR REITs clusters were distinct from other areas in metropolitan Nashville. In terms of population demographics, SFR REIT clusters: were somewhat less diverse, had higher levels of educational attainment, had somewhat larger households, had higher median household incomes, and lower poverty and unemployment rates. The housing stock in SFR REIT clusters was built more recently and had higher median housing values and rents. These characteristics were consistent with the literature on SFR REITs [3]. However, a closer examination of single-family units in SFR REIT clusters suggested that some characteristics diverged from the literature. When tenure and vacancy data for single-family units were examined the data suggested that: owner occupancy rates were higher in SFR REIT clusters, renter occupancy rates were lower in SFR REIT clusters, and vacancy rates were lower in SFR REIT clusters. In contrast to some of the literature [15], the data suggested that SFR REIT clusters were located in areas where the overall rental activity of single-family units was lower than the rest of the metropolitan area and vacancy rates among single-family units were lower. This suggests that SFR REITs clustered in areas where other types of multiple property owners were not actively engaged in the housing submarket, making institutional investors more visible.

Table 4 presents $t$-test results comparing non-SFR REIT tracts to SFR REIT tracts and comparing unclustered SFR REITs to SFR REIT clusters. The first three columns of Table 4 identify characteristics that were significantly different between non-SFR REIT and SFR REIT tracts. These results suggest that SFR REITs were more likely to appear in tracts where: there were fewer residents without a high school diploma, average household sizes were higher, median household incomes were higher, and poverty and unemployment rates were lower. SFR REITs were also more likely to appear in areas with newer housing stock, higher median rents, and where owner-occupied units were less likely to be cost burdened. These findings were consistent with other literature [3]. In contrast to some of the literature [15], the $t$-test results suggested that SFR REITs were more likely to appear in areas with higher owner-occupancy rates in single-family homes, and lower renter occupancy and vacancy rates in single-family homes. In essence, SFR REITs were more likely to appear in relatively stable housing markets, and SFR REITs were more visible in this segment of the market where rental activity was less pronounced. 
Table 4. T-Test Results for Non-REIT, REIT, and REIT Clusters (2015 ACS 5yr Estimates).

\begin{tabular}{|c|c|c|c|c|c|c|}
\hline & $\begin{array}{l}\text { Non-REIT Tracts } \\
\quad(N=156)\end{array}$ & $\begin{array}{l}\text { REIT Tracts } \\
(N=169)\end{array}$ & $\alpha<0.05$ & $\begin{array}{l}\text { Unclustered REITs } \\
\qquad(N=124)\end{array}$ & $\begin{array}{l}\text { REIT Clusters } \\
\quad(N=45)\end{array}$ & $\alpha<0.05$ \\
\hline Percent of Population White & 72 & 76 & & 76 & 77 & \\
\hline $\begin{array}{l}\text { Percent of Population } \\
\text { African American }\end{array}$ & 21 & 16 & & 17 & 15 & \\
\hline $\begin{array}{l}\text { Percent of Population } \\
\text { Hispanic/Latino }\end{array}$ & 7 & 7 & & 8 & 6 & * \\
\hline Median Age & 36.71 & 37.3 & & 37.59 & 36.52 & \\
\hline $\begin{array}{l}\text { Percent Less than } \\
\text { High School }\end{array}$ & 13 & 10 & * & 11 & 7 & * \\
\hline $\begin{array}{l}\text { Percent Bachelor's Degree } \\
\text { or Higher }\end{array}$ & 31 & 32 & & 31 & 35 & \\
\hline Average Household Size & 2.47 & 2.7 & * & 2.65 & 2.82 & * \\
\hline Median Household Income & $\$ 56,277$ & $\$ 64,499$ & * & $\$ 61,592$ & $\$ 72,507$ & * \\
\hline Percent Below Poverty & 19 & 11 & * & 12 & 7 & * \\
\hline Percent Unemployed & 8 & 6 & * & 6 & 5 & * \\
\hline Median Year Built & 1975 & 1988 & * & 1984 & 1997 & * \\
\hline Median Housing Value & $\$ 221,938$ & $\$ 198,826$ & & $\$ 195,196$ & $\$ 208,829$ & \\
\hline Median Rent & $\$ 929$ & $\$ 1039$ & * & $\$ 999$ & $\$ 1150$ & $*$ \\
\hline $\begin{array}{l}\text { Percent of Owner Occupied } \\
\text { Units Paying } 30 \% \text { or more } \\
\text { of Income on Housing }\end{array}$ & 25 & 23 & $*$ & 24 & 22 & \\
\hline $\begin{array}{l}\text { Percent of Renter Occupied } \\
\text { Units Paying } 30 \% \text { or more } \\
\text { of Income on Housing, }\end{array}$ & 44 & 42 & & 44 & 37 & $*$ \\
\hline $\begin{array}{l}\text { Percent of Single Family } \\
\text { Units Owner Occupied }\end{array}$ & 52 & 67 & $*$ & 64 & 75 & $*$ \\
\hline $\begin{array}{l}\text { Percent of Single Family } \\
\text { Units Renter Occupied }\end{array}$ & 14 & 12 & * & 12 & 11 & \\
\hline $\begin{array}{l}\text { Percent of Single Family } \\
\text { Units Vacant }\end{array}$ & 34 & 21 & * & 24 & 14 & $*$ \\
\hline
\end{tabular}

The last three columns of Table 4 identify characteristics that were significantly different between unclustered SFR REIT properties and SFR REIT clusters. These results suggest that SFR REITs were more likely to cluster in tracts: with smaller Latino populations, were there were fewer residents without a high school diploma, where household sizes were larger, where median household incomes were higher, and where poverty and unemployment rates were lower. SFR REITs were also more likely to cluster in areas with newer housing stock, higher median rents, and fewer renters that were cost burdened. These findings were consistent with the literature cited earlier in this article [3]. In contrast to some of the literature cited above, the $t$-test results suggested that SFR REITs were more likely to cluster in areas with higher owner-occupancy rates in single-family homes and lower vacancy rates in single-family homes. In essence, SFR REITs were more likely to cluster in areas with even more stable housing markets, and SFR REITs were most visible in this segment of the market where they crowded out non-institutional landlords.

Figure 1 visualizes the clusters of SFR REIT properties, highlighting the distinct geographies where census tracts had relatively large percentages $(>1 \%)$ of single-family units that were REITs. These clusters were mapped using GIS software. The map highlights some of the same tendencies noted above. There were 2318 properties identified in the 45 census tracts where SFR REITs clustered, representing 78\% of all SFR REIT properties in Metropolitan Nashville. Spatially, SFR REIT properties clustered in the relatively newer suburban area of Nashville, on the boundaries of Davidson County where the City of Nashville is located and other counties. Figure 1 also includes a density analysis which highlights hot spots where SDR REITs clustered. Although the scope of this analysis is exploratory in nature, it suggests distinct demographic patterns where SFR REITs cluster. 
Future analysis should include dimensions, such as more rigorous multivariate tests and statistical controls, time-series analysis, and more discrete parcel-level analysis.

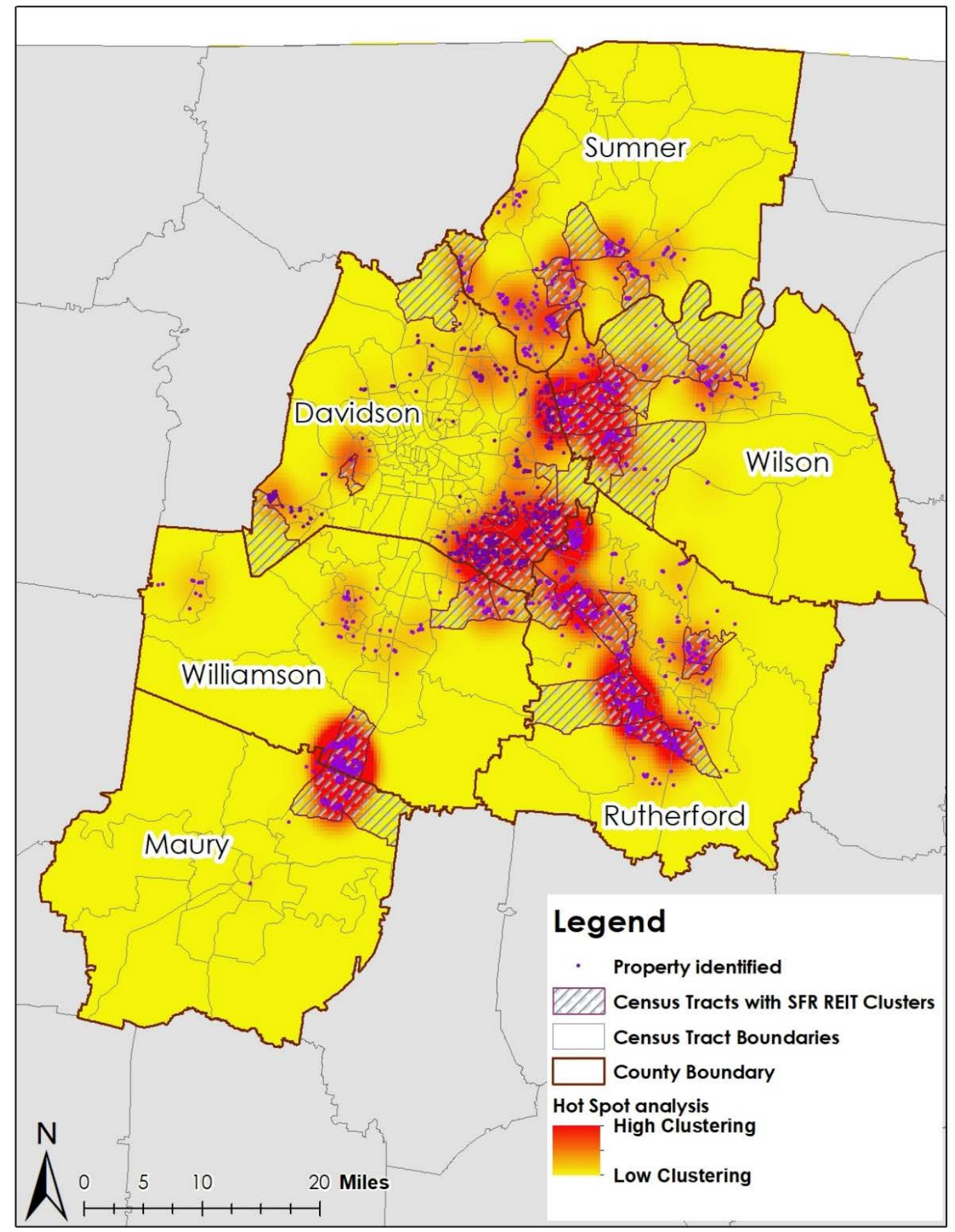

Figure 1. Single-family rental (SFR) real estate investment trusts (REIT) clusters in metropolitan Nashville, TN.

\section{Discussion and Conclusions}

The academic literature has not adequately analyzed the impacts of SFR REITs and other expressions of the increased financialization of regional housing markets, particularly in the U.S. context. An exception to this is found in Waldron's analysis of Irish REITs, where he cautions that the financialization of housing markets adds to the cost burden of homebuyers and renters at the local level while siphoning off the profits from real estate speculation to global investors [11]. These insights from the Irish context suggest that the potential impacts of the mass conversion of single-family housing 
to rental housing by institutional investors are immense and likely as important as gentrification and displacement in the urban core. The results from this analysis support the assertion that the financialization of local housing markets affects the supply of single-family housing and workforce housing. For example, one area where SFR REITs clusters were located in Nashville was in two census tracts bordering Williamson and Maury counties near General Motors former Saturn factory that currently produces other GM vehicles. Many of the workers in this facility earned competitive wages and sought viable housing options near the plant. The SFR REIT business model targets property in proximity to this cohort of potential homeowners. By purposely purchasing affordable homes with yards in communities with good schools and relatively safe profiles better resourced SFR REITs directly compete with potential homebuyer and expand the renter society. Other REIT clusters in Figure 1 have similar characteristics.

The Nashville metropolitan area has experienced tremendous population growth. In fact, the number of building permits issued in 2017 was higher than in the years before the Great Recession. Housing prices have increased tremendously in the region. Although development and growth have dominated the local agenda, particularly in relation to development within the city of Nashville proper, scant attention has been paid to the emergence of SFR REITs. The main newspaper, The Tennessean, has devoted considerable space to covering affordable housing issues, gentrification, and displacement. For example, in December of 2017, the Tennessean hosted a community meeting on gentrification that brought together housing advocates, developers, Airbnb owners, and community groups. None of those speakers talked about the impact of SFR REITs on local property markets. The discussion of affordable housing remained centered on the issue in the urban core along the lines of Kotler's [28] imperial city framework. The transformation of multiple property ownership in the suburbs and the growing influence of institutional investors as opposed to individual investors remains obfuscated. Insights from this analysis and the broader implications of financialization of real estate expand our understanding of the transformation that is underway in regional housing markets.

Our research suggests that the degree to which SFR REITs are major players in several metropolitan areas hard hit by the foreclosure crisis in 2008-2010 requires further scrutiny. Prior analysis of SFR REITs in the U.S. has not explored their impact on regional housing markets and their integration into the global financial system. For example, Abood [15] blames SFR REITs for promoting a rentership society, but the lack of empirical, statistical analysis of the impact of SFR REITs on home prices, appreciation, or ownership rates is too scarce at present to substantiate that claim. We also do not know enough about the impact of SFR REITs on smaller, locally-owned landlords. In Nashville, some smaller property owners have sold moderately sized portfolios of rental houses to SFR REITs. In addition, a local developer has teamed with American Homes 4 Rent to build a small subdivision of rental single-family housing. To date, we have found very little literature on this trend or its impact on housing markets.

A growing number of observers raise troubling questions about tenant rights and the quality of SFR REIT landlords [15,29]. A recent article by the Capital Forum found multiple problems with one of the largest SFR REITs, Invitation Homes. The Capital Forum maintains that Invitation Homes has engaged in deceptive practices that exploit tenants [30]. They contend that Invitation Homes buildings are poorly maintained, violate local codes and that the company is very slow in responding to tenant complaints and needs. A quick perusal of Landlord Forums on various internet platforms finds a number of customers who complain about the same issues as identified by the Capital Forum. A private Facebook group, Tenants of Invitation Waypoint Homes, unites dissatisfied customers across the country; the group discusses poor maintenance, problems with online payments, arbitrary rent increase, and the difficulty of getting deposit fees back when leases are broken. Yet, there has been little, if any, scholarly research on the topic. Moving forward, scholars need to conduct case studies of individual markets where SFR REIT landlords own large portfolios of housing.

We found no research on the impact of SFR REITs on single-family ownership opportunities in the scholarly research. The impacts will likely vary by individual markets based upon how robust 
the local housing market has rebounded from the $2008 \mathrm{crash}$. It will be difficult to disaggregate the multiple factors associated with home ownership that are not related to SFR REITs.

Finally, little is known about the impacts of SFR REITs on the local quality of life or how the growth of single-family rental housing in traditionally owner-occupied neighborhoods effects individual owners. Researchers have written about biases against rental housing in the past, but less is known about how SFR REIT clusters affect individual homeowner's perspectives about long-term equity, community safety, and community standards. In Nashville, many of the SFR REIT properties are located in subdivisions with home owners' associations (HOAs). There is evidence that some Nashville HOAs are aggressively trying to implement policies to limit the number of rental properties permitted in their communities. Future research should focus on ways that HOAs and individual homeowners are mobilizing to combat what many residents see as a negative trend. Finally, we reiterate the importance of expanding the scope of future analysis to include: more rigorous multivariate tests and statistical controls, time-series analysis, and more discrete parcel-level analysis. These types of analyses need to be applied to individual cases as well as in comparative contexts. Although the analysis used in this article is exploratory in nature, future analysis should include cross-national research that allows for a more dimensional examination of the financialization of housing markets following the global financial crisis.

Author Contributions: Conceptualization, K.C. and R.M.S.; Data curation, R.C. and C.W.; Formal analysis, K.C., R.M.S., R.C. and C.W.; Methodology, K.C. and R.M.S; Writing-original draft, K.C. and R.M.S.; Writing-review \& editing, K.C. and R.M.S.

Funding: University at Buffalo, Baldy Center for Law \& Social Policy, n/a.

Acknowledgments: Work that provided the basis for this publication was supported by a research grant from the Baldy Center for Law \& Social Policy at the University at Buffalo. We also thank the three anonymous reviewers for comments on earlier versions of this article.

Conflicts of Interest: The authors declare no conflict of interest.

\section{References}

1. Chan, S.H.; Erickson, J.; Wang, K. Real Estate Investment Trusts: Structure, Performance, and Investment Opportunities; Oxford University Press: New York, NY, USA, 2002; ISBN 978-019515534.

2. Newell, G.; Fischer, F. The Role of REITs in REIT Portfolios. J. Real Estate Portf. Manag. 2009, 15, 129-139.

3. Fields, D.; Kohli, R.; Schafran, A. The Emerging Economic Geography of Single-Family Rental Securitization; Federal Reserve Bank of San Francisco: San Francisco, CA, USA, 2016.

4. Amherst Capital Management. U.S. Single Family Rental: Institutional Activity in 2016/2017; Amherst Capital Management: New York, NY, USA, 2017.

5. Mills, J.; Molloy, R.; Zarutskie, R. Large-Scale Buy-to-Rent Investors in the Single-Family Housing Market: The Emergence of a New Asset Class. Real Estate Econ. 2017, 1-32. [CrossRef]

6. Aalbers, M. The Financialization of Housing: A Political Economy Approach; Routledge: London, UK, 2016.

7. Aalbers, M.B. The Variegated Financialization of Housing. Int. J. Urban Reg. Res. 2017, 41, 542-554. [CrossRef]

8. Fields, D. Unwilling Subjects of Financialization. Int. J. Urban Reg. Res. 2017, 41, 588-603. [CrossRef]

9. Fields, D. Constructing a New Asset Class: Property-led Financial Accumulation After the Crisis. Econ. Geogr. 2018, 94, 118-140. [CrossRef]

10. Gotham, K.F. The Secondary Circuit of Capital Reconsidered: Globalization and the U.S. Real Estate Sector. Am. J. Sociol. 2006, 112, 231-275. [CrossRef]

11. Waldron, R. Capitalizing on the State: The Political Economy of Real Estate Investment Trusts and the 'Resolution' of the Crisis. Geoforum 2018, 90, 206-218. [CrossRef]

12. Alexandri, G.; Jampscka, M. Who Loses and Who Wins in a Housing Crisis?: Lessons from Spain and Greece for a Nuanced Understanding of Dispossession. Hous. Policy Debate 2018, 28, 117-134. [CrossRef]

13. Wijburg, G.; Aalbers, M.B.; Heeg, S. The Financialisation of Rental Housing 2.0; Releasing Housing into the Privatised Mainstream of Capital Accumulation. Antipode 2018, 50, 1098-1119. [CrossRef]

14. Glink, I. 10 Worst Cities for Foreclosures in 2010. CBS News Moneywatch. Available online: https://www. cbsnews.com/news/10-worst-cities-for-foreclosures-in-2010/ (accessed on 12 February 2018). 
15. Abood, M. Wall Street Landlords Turn America Dream into a Nightmare; ACCE Institute: Los Angeles, CA, USA, 2018; p. 5.

16. Federal Reserve Banks of Boston and Cleveland and the Federal Reserve Board. REO \& Vacant Properties: Strategies for Neighborhood Stabilization. Available online: https:/ / www.bostonfed.org/publications / one-time-pubs/reo-vacant-properties-strategies-for-neighborhood-stabilization.aspx (accessed on 12 February 2018).

17. Reid, C.K. Shuttered Subdivisions: REOs and the Challenges of Neighborhood Stabilization in Suburban Cities. In REO \& Vacant Properties: Strategies for Neighborhood Stabilization. A Joint Publication of the Federal Reserve Banks of Boston and Cleveland and the Federal Reserve Board; Federal Reserve Bank of Boston: Boston, MA, USA, 2010; pp. 23-32. Available online: https://www.bostonfed.org/publications/one-time-pubs/reovacant-properties-strategies-for-neighborhood-stabilization.aspx (accessed on 12 February 2018).

18. Immergluck, D. Holding or folding? Foreclosed Property Durations and Sales During the Mortgage Crisis. In REO \& Vacant Properties: Strategies for Neighborhood Stabilization. A Joint Publication of the Federal Reserve Banks of Boston and Cleveland and the Federal Reserve Board; Federal Reserve Bank of Boston: Boston, MA, USA, 2010; pp. 33-46. Available online: https:/ / www.bostonfed.org/publications / one-time-pubs/reo-vacantproperties-strategies-for-neighborhood-stabilization.aspx (accessed on 12 February 2018).

19. Donner, H. Foreclosures, Returns, and Buyer Intentions. J. Real Estate Res. 2017, 39, 189-213.

20. McKee, K.; Moore, T.; Soaita, A.; Crawford, J. 'Generation Rent' and the Fallacy of Choice. Int. J. Urban Reg. Res. 2017, 41, 318-333. [CrossRef]

21. Ronald, R.; Kadi, J. The revival of private landlords in Britain's Post-Homeownership Society. New Political Econ. 2017, 23, 786-803. [CrossRef]

22. Strochak, S. Five Things That Might Surprise You about the Fastest-Growing Segment of the Housing Market. Urban Institute Urban Wire. 2017. Available online: https:/ / www.urban.org/urban-wire/five-things-mightsurprise-you-about-fastest-growing-segment-housing-market (accessed on 14 March 2018).

23. Wiggin, T. Welcome to Wall Street's Housing Market. Available online: https://www.inman.com/2017/06/ 09/welcome-to-wall-streets-housing-market/ (accessed on 14 March 2018).

24. Edelman, S.; Gordon, J.; Sanchez, D. When Wall Street Buys Main Street: The Implications of Single-Family Rental Bonds for Tenants and Housing Markets; Center for American Progress: Washington, DC, USA, 2014.

25. Fields, D. The Rise of the Corporate Landlord: The Institutionalization of the Single-Family Rental Market and Potential Impacts on Renters; The Right to the City Alliance: New York, NY, USA, 2014.

26. Amherst Capital Management. U.S. Single Family Rentals: An Emerging Institutional Asset Class; Amherst Capital Management: New York, NY, USA, 2016.

27. U.S. Department of Housing and Urban Development. Comprehensive Housing Market Analysis: Nasville-Davidson-Murfreesboro-Franklin, Tennessee; U.S. Department of Housing and Urban Development: Washington, DC, USA, 2017. Available online: https://www.huduser.gov/portal/publications/pdf/ NashvilleTN-comp-17.pdf (accessed on 27 August 2018).

28. Kotler, M. Neighborhood Government: The Local Foundations of Political Life; Lexington Books: Lanham, MD, USA, 2004; ISBN 978-0739109915.

29. The Capital Forum. Single-family Rental Industry: Companies Lean on Tenant Chargebacks to Effectively Cut Operating Expenses. Available online: https:/ thecapitolforum.com/wp-content/uploads/2018/03/ SFR-Industry-2018.02.21.pdf (accessed on 1 March 2018).

30. The Capital Forum. Single-Family Rental Industry: Company Keeps Tenant Security Deposits, Pad Move-Out Statements, Turn Former Tenants' Accounts over to Debt Collectors. Available online: http:/ / createsend. com/t/j-C6FE0B7A08F706392540EF23F30FEDED (accessed on 3 March 2018).

(C) 2018 by the authors. Licensee MDPI, Basel, Switzerland. This article is an open access article distributed under the terms and conditions of the Creative Commons Attribution (CC BY) license (http:/ / creativecommons.org/licenses/by/4.0/). 